\title{
THE COMBINED EFFECT OF ULTRASONIC EXPOSURE AND PROTEIN RESTRICTION ON MATERNAL AND FETAL MICE
}

\author{
Hyun-kyung Lee Kim and Mary Frances Picciano \\ Food and Nutrition Department, Nutritional Sciences Program, University of Illinois, 905 S. Goodwin Ave., Urbana, \\ IL 61801, U.S.A. \\ and \\ WiLliam D. O'Brien, JR. $†$ \\ Bioacoustics Research Laboratory, Electrical Engineering Department, University of Illinois, 1406 W. Green St., Urbana, \\ IL 61801, U.S.A.
}

(First received 31 March 1982; in final form 21 August 1982)

\begin{abstract}
This investigation was undertaken to assess the combined effects of protein restriction and ultrasonic energy exposure during pregnancy on the maternal and fetal mouse. Pregnant female mice were fed diets containing either $18 \%$ casein (control diet) or $6 \%$ casein (restricted protein diet) during gestation. All animals were subjected to the ultrasonic exposure procedure (actual: $2.5 \mathrm{~W} / \mathrm{cm}^{2}$ spatial peak; sham: $0 \mathrm{~W} / \mathrm{cm}^{2}$; continuous wave for $20 \mathrm{sec}$ at a frequency of 1 $\mathrm{MHz}$ ) on day 8 of gestation. On day 18 of gestation, the animals were sacrificed. Products of conception were examined, and chemical analysis were performed on maternal liver, placenta and fetus.

Our results suggest that there are possible influences of ultrasonic energy exposure to the mouse fetus and placenta, as indicated by the tendency toward decreases of fetal weight, placental weight, and DNA and RNA contents of both fetus and placenta, especially with restricted protein in the maternal diet during gestation.

Protein restriction during pregnancy had an adverse influence on both the maternal organism and her products of conception. The nutritional needs for the fetus were not met at the expense of the maternal organism. Parameters of fetal cellular growth were reduced by gestational protein restriction indicating that there is competition for available nutrients between the fetus under time of stress. Results also show that the trends of fetal and placental growth are in the same general direction suggesting the possible usefulness of human placental tissue as a maker for fetal growth in subsequent population studies.
\end{abstract}

Key Words: Ultrasonic energy, Protein-deficient diet, Mice, Fetus, Placenta, Uterus, Resorption site, Maternal liver, Fatty liver, Gestational performance, Food intake, Body weight gain, Body composition, Cellular growth, Cell number, Cell size, Deoxyribonucleic acid (DNA), Ribonucleic acid (RNA), Protein, Lipids.

\section{INTRODUCTION}

In the clinical practice of obstetrics, ultrasound provides a visual method of evaluating normal and abnormal fetuses, placental problems, and uterine disorders (Gottesfeld 1978). The increased use of ultrasonic energy in obstetrics dictates that a reliable assessment of its risks to human populations has to be performed. It has been shown that fetal weight depression does occur as a result of exposure to ultrasound during the prenatal period in certain mouse strains (O'Brien 1976 and 1982; Stratmeyer et al. 1977; Stolzenberg et al. 1980a; Stolzenberg et al. 1980b). There is also evidence to show that maternal body weight is decreased from in utero ultrasonic exposure (Stolzenberg et al. 1980a) and that fetal weight reduction may be sustained post weaning (Stratmeyer 1981).

At the same time, increased emphasis has been placed upon the effects of maternal nutrition on

tAuthor to whom all correspondence should be addressed. the outcome of gestation, particularly the effect of maternal protein intake on fetal growth and development (Metcalf et al. 1981). Growth and development of the fetus depends on a steady supply of nutrients from the mother, and thus the reduction of protein during pregnancy might be harmful to the developing organism. Experimental data from both human (Burke et al. 1943; Lechtig et al. 1975) and animal studies (Kohrs et al. 1976; Pond et al. 1968; Zeman and Stanbrough 1969) indicate that there is a positive relationship between maternal protein malnutrition during pregnancy and subsequent adverse effects on fetal growth and development.

It is still unclear, however, whether adequate growth and development of the fetus could occur at the expense of the maternal organism during fetal ultrasonic exposure and/or maternal protein restriction. Therefore, attention has to be focused on maternal tissue changes and their relationship to fetal growth during fetal ultrasonic exposure 
and/or maternal protein reduction; then it is possible to assess the role of maternal tissues as a proper barrier for protecting the fetus. It is also important to investigate whether these stresses are related to placental growth and whether the placental growth pattern reflects the fetal condition. The human fetus is obviously not available for investigation, but the placenta is an available human reproductive tissue. It has been shown that normal placental growth in rats proceeds in the same way as in their fetal organs (Winick and Noble 1966). The same general pattern of cellular growth has been reported for human placenta (Winick et al. 1967), although the timing is somewhat different. If the pattern of changes in placental growth and development is correlated with that of fetal tissues in animals, similar changes in human placenta could provide a clue on how environmental stresses imposed on the female during pregnancy influence the human fetus.

Although the above cited studies indicate that either ultrasonic energy exposure or prenatal protein deprivation adversely effect fetal growth and development, the combined effects of these two stresses on either the fetus or the maternal organism have not been explored in either human or experimental animals. Since it is difficult if not impossible to adequately evaluate the combined effects of these two stresses on human subjects, the use of an animal model is warranted.

This investigation was undertaken to assess the combined effects of a protein restricted diet and ultrasonic energy exposure during pregnancy on the maternal and fetal mouse. In addition, it was sought to determine whether the pattern of placental growth in this animal model could serve as a guide to fetal growth, and whether maternal tissues serve as a barrier providing fetal protection against these stresses.

\section{MATERIALS AND METHODS}

\section{Experimental design}

The design of this study was $2 \times 2$ factorial where two levels of dietary protein [control (C) and restricted (R)] and two ultrasonic exposure conditions [sham (S) and actual (A)] were applied to pregnant mice, viz. CS, CA, RS, RA.

\section{Animals}

Conventionally reared $\mathrm{LAF}_{1} / \mathrm{J}$ mice (Jackson Lab, Bar Harbor, Maine) were proven breeders weighting between 24 and $31 \mathrm{~g}$. Mating occurred by placing five females and two males together for a 2-hr period (from 8:00 a.m. to 10:00 a.m.) and judged successful by the presence of a vaginal plug which was considered day zero of gestation. On day zero, the pregnant females were randomly assigned to one of two dietary regimens and remained there throughout gestation.

The animals were kept in a temperature-controlled room $\left(20^{\circ} \mathrm{C}\right)$ with alternate 12 -hr light-dark periods. Pregnant females were housed individually in polypropylene "show-box" cages with Sanicel bedding (Paxton Processing Company, Inc., Paxton, IL).

\section{Diets}

All animals were fed a commercial lab feed (Wayne Lab-Blox, Allied Mills, Inc., Chicago, IL) until they were mated after which purified diets were used.

Since an $18 \%$ casein diet was recommended by the National Academy of Science (1978) for satisfactory reproduction of mice, and an improvement of reproductive performances of mice was observed with increasing dietary fat from 5 to $15 \%$ in a previous study (Kim et al., 1981), the purified control diet (protein adequate diet) contained $18 \%$ casein and $15 \%$ fat (Table 1). The protein-restricted diet, which was isocaloric to the control diet, contained $6 \%$ casein and $15 \%$ fat. Food and water were provided ad libitum until the time of sacrifice. All purified diets were incorporated into a $2 \%$ agar gel (1:1, dry diet:water) to reduce wastage and to facilitate the determination of food intake. The caloric density of both diets was 4.5 $\mathrm{kcal} / \mathrm{g}$.

\section{Animal irradiation}

The following irradiation procedure was used in the study. On day 8 of gestation the pregnant mice were anesthetized with "Metofane" (methoxyfluorane, Pitman-Moore, Inc., Washington Crossing, NJ). Abdominal, both sides, and dorsal surface hair was removed with an electric clipper. A commercial dipilatory was applied to remove stubbles. The animals were mounted on a holder in a "Spread-eagle" fashion and positioned in the exposure tank which contained normal saline $(0.9 \%)$ at a temperature of $37^{\circ} \mathrm{C}$.

A matrix pattern of exposures was used to provide a uniform exposure over the abdominal area. At the site of but without the mouse in place, the $95 \%$ intensity beam width was $1 \mathrm{~cm}$ and thus a matrix of 2 shots across by 3 shots down (centerto-center distance of $1 \mathrm{~cm}$ ) was utilized. The ultrasonic intensity reported herein has an accuracy of $\pm 3 \%$ (Dunn et al. 1977). Even though 
Table 1. Composition percentage ( $w / w)$ of control and restricted protein diets. Diets were prepared in a $2 \%$ agar gel $(1: 1$, dry diet: water) and provided a caloric density of $4.5 \mathrm{kcal} / \mathrm{g}$

\begin{tabular}{|c|c|c|c|}
\hline \multirow[b]{2}{*}{ Ingredient } & \multirow[b]{2}{*}{ Supplier } & \multicolumn{2}{|c|}{$\because$ diet $(w / w)$} \\
\hline & & control (C) & restricted protein (R) \\
\hline casein & $\begin{array}{l}\text { Teklad } \\
\text { (Yad1son, WI) }\end{array}$ & 18.0 & 6.0 \\
\hline L-methlonine & $\begin{array}{l}\text { Ajinowoto Co. Ine. } \\
\text { (Tokyo, Japan) }\end{array}$ & 0.5 & 0.5 \\
\hline corn oil & $\begin{array}{l}\text { Nutritional Blochemicals } \\
\text { (Cleveland, } O H)\end{array}$ & 10.0 & 10.0 \\
\hline lard & $\begin{array}{l}\text { Nutritional Blochemicals } \\
\text { (Cleveland, DH) }\end{array}$ & 5.0 & 5.0 \\
\hline corn starch & $\begin{array}{l}\text { A. E. Staley Mf } 8 \cdot C c \text {. } \\
\text { (Decatur, IL) }\end{array}$ & 51.3 & 51.3 \\
\hline D-Dextrose & $\begin{array}{l}\text { Nutritional Biochemlcals } \\
\text { (Cleveland, } \mathrm{OH})\end{array}$ & 9.2 & $2 ! .2$ \\
\hline $\begin{array}{l}\text { Rogers-Harper } \\
\text { sait nixture }\end{array}$ & $\begin{array}{l}\text { Teklad } \\
\text { (Madison, WI) }\end{array}$ & 5.0 & 5.0 \\
\hline $\begin{array}{l}\text { vitanin fortification } \\
\text { mixture (Cat } \$ 40060)\end{array}$ & $\begin{array}{l}\text { Teklad } \\
\text { (Madison, HI) }\end{array}$ & 1.0 & 1.0 \\
\hline
\end{tabular}

six shots per exposure were employed, the ultrasonic exposure parameters represent the spatial peak intensity (actual of $2.5 \mathrm{~W} / \mathrm{cm}^{2}$ and sham of $0 \mathrm{~W} / \mathrm{cm}^{2}$ ) and exposure time per shot of $20 \mathrm{sec}$.

The exposure procedure was controlled by a computer and permitted a blind study where the actual and sham exposed animals were randomly determined without the operator's knowledge. Mice were then immediately wrapped in a tissue to prevent chilling and placed in their respective cages.

\section{Tissue analyses}

During gestation, all maternal animals were weighed at regular intervals, and records of weight gain were kept for each. All dams were killed by cervical dislocation on day 18 of gestation, because it is generally considered that the average gestational period of mice is 19 days (Rugh 1968). At the time of dissection, maternal liver, all fetuses, and placentas were excised and immediately frozen at $-25^{\circ} \mathrm{C}$ for subsequent compositional analysis.

The following data were recorded at the time of sacrifice: (1) maternal body weight; (2) maternal liver weight; (3) weight of uterus and its contents; (4) litter size; (5) number of resorption sites per dam; (6) individual fetal weight; and (7) individual placental weight. Also, the uteri of dams were carefully examined for the presence of implantation sites to determine whether the sites were normal or in the process of resorption. A placental to fetal ratio for each animal was calculated from these data. The weights of uterine tissue and fluids were also calculated by subtracting the weights of fetuses and placentas from weights of uterine mass. Randomly chosen fetuses and placentas from each mother were assayed for DNA, RNA, protein, lipids, and ash contents. Maternal liver was also analyzed for DNA, RNA, protein and lipids contents. The nucleic acids were isolated by a modification of the method of Schmidt-Thanhouser (Fleck and Munro 1962), in which the homogenate was precipitated with trichloroacetic acid, washed with alcohol-ether mixture, and dissolved in $0.3 \mathrm{~N} \mathrm{NaOH}$ solution. The resulting solution was used for the determination of DNA and RNA. DNA was measured by the method of Hubbard et al. (1970). RNA was determined by the colorimetric method of Ceriotti (1955). Total lipids were determined by the method of Folch et al. (1957). Protein was measured colorimetrically (Leshner and Litwin, 1972). The ash content of the fetus was measured gravimetrically after complete 
combustion in a muffle furnace at $550^{\circ} \mathrm{C}$ for $8 \mathrm{hr}$ (Association of Official Analytical Chemists, 1975). The ratios of protein to DNA, RNA to DNA, lipids to DNA, lipids to RNA, protein to RNA, and protein to lipids were calculated as the means of assessing cellular changes with maternal nutrition and/or ultrasonic energy exposure.

\section{Statistical analyses}

Analysis of variance, Duncan's multiple range, regression and correlation statistics (Steel and Torrie 1960) were used in data evaluation. Student's t-test was also used to determine whether the correlation coefficient obtained from the correlation analysis was statistically significant. A probability value of less than 0.05 was taken as the level of significance.

Regression analysis was applied to the maternal body weight and maternal food intake by assuming a linear, first order model and by utilizing a least squares estimation procedure, thus yielding the slope and intercept, their significance and their 95\% confidence limits (Draper and Smith, 1966).

\section{RESULTS}

Maternal food and caloric intakes during gestation

Daily cumulative food and caloric intakes of maternal animals during gestation are presented in Fig. 1. Analysis of variance of data shows that protein content in the diet has a significant influence on maternal food intake from day 10 onward during gestation, while the effect of ultrasonic exposure on maternal food intake was negligible. Further, a regression analysis supports this conclusion based upon the $95 \%$ confidence limits for the slope of food intake as a function of time. During the first half of the pregnancy, maternal food intake did not change markedly, but as pregnancy progressed there was an increase in food intake in all groups. The increase in food intake was more marked in control diet groups (CS and CA) than in protein-restricted groups (RS and RA). This trend was maintained for the remainder of pregnancy and consequently, the total food intake of the control diet groups significantly exceeded those of the protein-restricted diet groups over the period of the pregnancy. Since the protein-restricted diet was isocaloric with the control diet, the decrease in food intake resulted in a significant reduction in biocaloric consumption.

\section{Dam body weight gain during gestation}

There were minimal effects of ultrasonic exposure or its interaction with a protein restricted

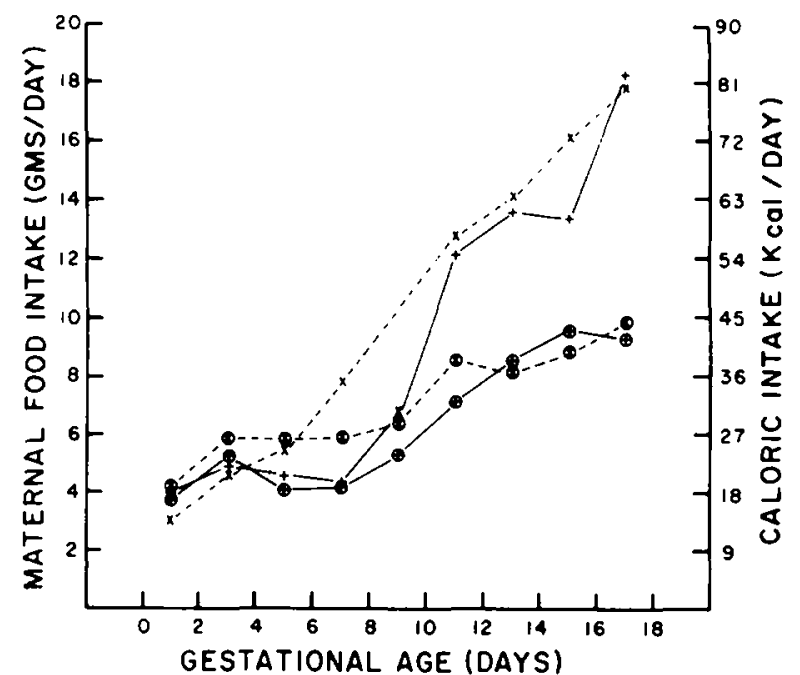

Fig. 1. Daily food (dry weight basis) and caloric intakes of maternal mice during gestation. Results are means of 6-9 dams with typical standard deviations ranging from $40 \%$ at early gestation to $20 \%$ at late gestation. Control diet-sham ultrasound exposure $(+)$, control diet-actual ultrasound exposure $(x)$, restricted protein diet-sham ultrasound exposure $(\otimes)$ and restricted protein diet-actual ultrasound exposure $(\oplus)$.

diet on parameters of gestational performance as listed in Table 2. A decrease in dietary protein content resulted in an increase in the number of resorption sites per dam, but no statistically significant effect was observed on litter size. When data were expressed in terms of percentage of total implants, percentage resorptions were markedly increased by a decrease in protein level in diets of dams.

There was an increase in dam body weight in all groups as pregnancy progressed (Fig. 2 and Table 2). The general pattern of increase in dam body weight consisted of a $10-13 \%$ increase up to day 8 of gestation and a much greater rate of increase (21-30\%) through the latter part of gestation. Total body weight gain in protein-restricted diet groups was significantly lower than that in control groups over the period of pregnancy.

Dam body weight gain was significantly decreased by a reduction of dietary protein to one-third of the control level. No interaction was observed between protein restriction and ultrasonic energy exposure on dam body weight gain.

\section{Weights of the uterus and its content}

The total weight of the uterine mass (Table 2) was significantly reduced by lowering the protein content in diets. It was due to a significant decrease in individual fetal weight in the restricted protein diet groups. Placental weight and uterine 
Table 2. The combined effects of ultrasound and protein nutrition on gestation performance and mean weights of dams and their products of conception'

\begin{tabular}{|c|c|c|c|c|c|c|c|c|}
\hline & \multicolumn{8}{|c|}{ Treatannt } \\
\hline & \multicolumn{2}{|r|}{ cs } & \multicolumn{2}{|r|}{$\underline{\mathrm{CA}}$} & \multicolumn{2}{|r|}{$\underline{\mathrm{RS}}$} & \multicolumn{2}{|r|}{$\underline{\mathbf{R A}}$} \\
\hline Number of dane & \multicolumn{2}{|r|}{6} & \multicolumn{2}{|r|}{8} & \multicolumn{2}{|r|}{9} & \multicolumn{2}{|r|}{9} \\
\hline Number of fetuses & \multicolumn{2}{|r|}{36} & \multicolumn{2}{|r|}{55} & \multicolumn{2}{|r|}{48} & \multicolumn{2}{|r|}{48} \\
\hline Number of Iaplante per dax & 8.2 & \pm 0.3 & 7.9 & \pm 0.4 & 8.0 & \pm 0.5 & 8.7 & \pm 0.3 \\
\hline $\begin{array}{l}\text { Resorptions per dan } \\
\text { Total number } \\
\% \text { of total implants }\end{array}$ & $\begin{array}{r}2.2 \\
24.3\end{array}$ & \pm 0.5 & $\begin{array}{r}1.0 \\
13.4\end{array}$ & $\begin{array}{l} \pm 0.4 \\
\pm 6.4\end{array}$ & $\begin{array}{r}2.7 \\
31.9\end{array}$ & $\begin{array}{r} \pm 0.9 \\
\pm 8.6\end{array}$ & $\begin{array}{r}3.3 \\
39.8\end{array}$ & $\begin{array}{l} \pm 0.6 \\
\mp 5.8\end{array}$ \\
\hline Litter slze per dan & 6.0 & \pm 0.4 & 6.9 & \pm 1.1 & 3.3 & \pm 1.0 & 5.3 & \pm 0.9 \\
\hline $\begin{array}{l}\text { Dan body weight } \\
\text { At day zero gestation } \\
\text { At day } 18 \text { geatar1on } \\
\text { Net galn }\end{array}$ & $\begin{array}{l}28.6 \\
43.3 \\
14.7\end{array}$ & $\begin{array}{l} \pm 0.7 \\
\pm 1.2 \\
\pm 1.0\end{array}$ & $\begin{array}{l}28.6 \\
44.6 \\
16.0\end{array}$ & $\begin{array}{l} \pm 0.7 \\
\pm 1.7 \\
\pm 1.2\end{array}$ & $\begin{array}{l}28.0 \\
39.5 \\
11.5\end{array}$ & $\begin{array}{l} \pm 0.1 \\
\pm 1.6 \\
\pm 1.1\end{array}$ & $\begin{array}{r}27.6 \\
37.2 \\
9.6\end{array}$ & $\begin{array}{l} \pm 0.7 \\
\pm 0.5 \\
\pm 0.8\end{array}$ \\
\hline $\begin{array}{l}\text { Total wight of uterine per pup } 2,3 \\
g^{\star \star} \\
z \text { of dam wight }\end{array}$ & $\begin{array}{l}1.52 \\
3.51\end{array}$ & $\begin{array}{l} \pm \pm 0.04 \\
\pm 0.04\end{array}$ & $\begin{array}{l}1.55 \\
3.59\end{array}$ & $\begin{array}{l} \pm 0.03 \\
\pm 0.26\end{array}$ & $\begin{array}{l}1.47 \\
3.79\end{array}$ & $\begin{array}{l} \pm 0.05 \\
\pm 0.25\end{array}$ & $\begin{array}{l}1.34 \\
3.62\end{array}$ & $\begin{array}{l} \pm 0.04 \\
\pm 0.12\end{array}$ \\
\hline $\begin{array}{l}\text { Petal welght } \\
g^{\star \star} \\
z \text { of dan weight }\end{array}$ & $\begin{array}{l}0.97 \\
2.28\end{array}$ & $\begin{array}{l}7 \pm 0.05 \\
8 \pm 0.07\end{array}$ & $\begin{array}{l}1.02 \\
2.30\end{array}$ & $\begin{array}{l} \pm 0.06 \\
\pm 0.24\end{array}$ & $\begin{array}{l}0.91 \\
2.34\end{array}$ & $\begin{array}{l} \pm 0.03 \\
\pm 0.11\end{array}$ & $\begin{array}{l}0.82 \\
2.19\end{array}$ & $\begin{array}{l} \pm 0.06 \\
\pm 0.15\end{array}$ \\
\hline $\begin{array}{l}\text { Placental weight }{ }^{3} \\
\text { ng of dan weight }\end{array}$ & $\begin{array}{r}102.5 \\
0.24\end{array}$ & $\pm \begin{array}{l} \pm .1 \\
\pm 0.02\end{array}$ & $\begin{array}{c}96.4 \\
0.22\end{array}$ & $\begin{array}{l} \pm 2.7 \\
\pm 0.01\end{array}$ & $\begin{array}{c}94.1 \\
0.24\end{array}$ & $\pm \frac{ \pm .4}{ \pm} 0.02$ & $\begin{array}{c}88.8 \\
0.24\end{array}$ & $\begin{array}{l} \pm 4.7 \\
\pm 0.01\end{array}$ \\
\hline $\begin{array}{l}\text { Weight of Uterine tisaue and fluld per pup } 3 \\
\qquad \frac{g}{z} \text { of dan welght }\end{array}$ & $\begin{array}{l}0.44 \\
1.03\end{array}$ & $\begin{array}{l} \pm 0.01 \\
\pm 0.05\end{array}$ & $\begin{array}{l}0.46 \\
1.08\end{array}$ & $\begin{array}{l} \pm 0.05 \\
\pm 0.15\end{array}$ & $\begin{array}{l}0.46 \\
1.22\end{array}$ & $\begin{array}{l} \pm 0.06 \\
\pm 0.20\end{array}$ & $\begin{array}{l}0.46 \\
1.25\end{array}$ & $\begin{array}{l} \pm c .06 \\
\pm 0.16\end{array}$ \\
\hline Petus/Placenta (ng/ng) & 9.75 & \pm 0.95 & 10.57 & \pm 0.48 & 10.04 & \pm 0.71 & 9.19 & \pm 0.51 \\
\hline
\end{tabular}

IResult: are mens \pm S.E.

${ }^{2}$ Sum of fetal weights, placental weights, uterine horns, and fluids expressed on a per pup besis.

3 Sum of mean value for each litter divided by muber of dane.

- A significant effect of protein-restricted diet was show at the level of $p<0.05$.

*A sigaificant effect of procela-reetricted dfet wes shom at the level of $p<0.01$.

tissue and fluid weight per pup were not significantly influenced by treatment. However, there appears to be a trend toward a reduction in weights of fetuses, placentas and uterine mass due to ultrasonic energy exposure in restricted protein dietary groups, although the effect of ultrasonic energy exposure on these weights was not shown to be statistically significant. The ratios of fetal to placental weights were essentially the same for all groups.

\section{Characteristics of dam liver}

Data on dam liver weight and total contents of lipids and protein in liver are reported on Table 3. The liver weight of dams maintained on restricted protein diets during gestation were significantly reduced as compared with those of controls, but there was no effect of dietary protein level on the relative weight of liver (liver weight/maternal body weight). Liver lipids of dams fed protein restricted diets were significantly higher than those of con- 
trols. Also the protein content of livers from protein restricted dams was significantly reduced. Accordingly, a significant reduction in the protein to lipid ratio was observed in the protein restricted diet groups. The livers from animals fed protein restricted diet were pale or yellow in color, and they were often fragile.

Neither ultrasonic energy exposure alone nor in combination with the protein restricted diet had any effect on liver weight, liver weight to body weight ratio, and liver lipid and protein contents of dams.

Animals fed the protein restricted diet had a higher concentration of liver DNA (mg/g liver) than those fed the control diet but there was no difference in total DNA/liver among groups. In contrast, the concentration of liver RNA $(\mathrm{mg} / \mathrm{g}$ liver) as well as the total RNA per liver did not differ among groups.

Although no difference in the amount of RNA

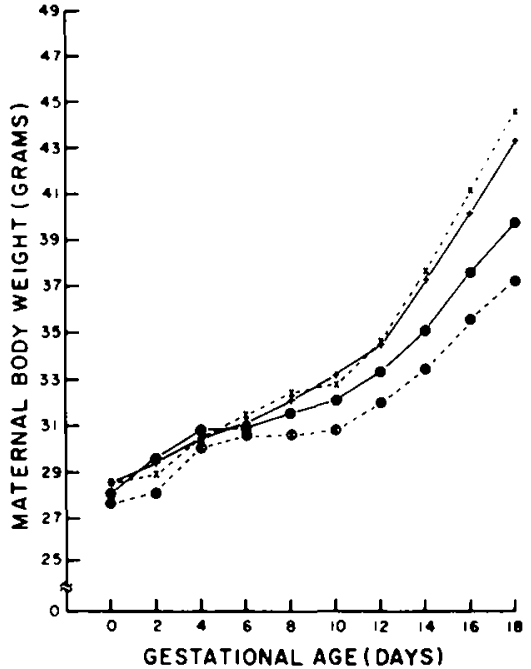

Fig. 2. Daily body weight of maternal mice during gestation. Results are means of 6-9 dams. Control diet-sham ultrasound exposure $(+)$, control diet-actual ultrasound exposure $(x)$, restricted protein diet-sham ultrasound exposure $(\oplus)$ and restricted protein diet-actual ultrasound exposure $(\otimes)$.

Table 3. The combined effects of ultrasound and protein nutrition on liver composition and cellular components of maternal mice ${ }^{1.2}$

\begin{tabular}{|c|c|c|c|c|c|c|}
\hline \multirow[b]{3}{*}{ Liver welght $(g)^{\star}$} & \multicolumn{6}{|c|}{ Treatuent } \\
\hline & & CS & $\underline{\mathrm{CA}}$ & $\underline{\text { RS }}$ & & $\underline{\mathrm{RA}}$ \\
\hline & 2.03 & \pm 0.08 & $1.93 \pm 0.10$ & $1.80 \pm$ & 0.11 & $1.77 \pm 0.06$ \\
\hline $\begin{array}{l}\text { Liver we1ght/maternal body } \\
\text { welght }(\mathrm{mg} / \mathrm{g})\end{array}$ & 46.9 & \pm 0.5 & $43.4 \pm 1.8$ & $45.7 \pm$ & 1.8 & $47.7 \pm 1.6$ \\
\hline Liplds (mg/g liver)** & 59.7 & \pm 6.0 & $67.8 \pm 6.6$ & $106.0 \pm$ & 11.1 & $106.8 \pm 9.7$ \\
\hline Protein (ag/g liver)** & 232.3 & \pm 13.7 & $226.7 \pm 9.9$ & $204.0 \pm$ & 5.1 & $203.2 \pm 7.6$ \\
\hline Prote1n/L1pids (mg/ng)** & 3.98 & \pm 0.22 & $3.49 \pm 0.22$ & $2.05 \pm$ & 0.16 & $2.00 \pm 0.15$ \\
\hline DNA (mg/IIver) & 6.83 & \pm 0.34 & $6.45 \pm 0.34$ & $6.65 \pm$ & 0.46 & $6.61 \pm 0.48$ \\
\hline DNA (ng/g Ifver)* & 3.36 & \pm 0.11 & $3.24 \pm 0.12$ & $3.71 \pm$ & 0.17 & $3.67 \pm 0.21$ \\
\hline RNA (mg/liver) & 16.08 & \pm 1.11 & $15.11 \pm 1.02$ & $14.37 \pm$ & 0.95 & $13.60 \pm 0.56$ \\
\hline RNA (mg/g I1ver) & 7.88 & \pm 0.31 & $7.81 \pm 0.24$ & $7.97 \pm$ & 0.15 & $7.68 \pm 0.27$ \\
\hline RNA/DNA (mg/Og) & 2.35 & \pm 0.06 & $2.43 \pm 0.10$ & $2.18 \pm$ & 0.12 & $2.13 \pm 0.13$ \\
\hline Protein/DNA (mg/ng) & 69.38 & \pm 4.55 & $70.37 \pm 2.98$ & $55.55 \pm$ & 1.90 & $56.60 \pm 4.10$ \\
\hline Prote1n/RNA (ag/mg)* & 29.52 & \pm 1.38 & $28.99 \pm 0.73$ & $25.69 \pm$ & 0.86 & $26.82 \pm 1.59$ \\
\hline LIp1d/DNA (mg/mg) $\star \star n t$ & 17.94 & \pm 2.11 & $21.18 \pm 2.41$ & $28.41 \pm$ & 2.37 & $29.55 \pm 2.94$ \\
\hline
\end{tabular}

$1_{\text {Results are weans } \pm S . E .}$

Wet weight basis

* A signiflcant effect of protein-restricted diet was shown at the level of $p<0.05$.

**A significant effect of protein-restricted diet wes shown at the level of $p<0 .)$.1 . 
per cell (RNA/DNA ratio) was observed among groups, the relative cellular protein (protein/DNA ratio) and lipid (lipid/DNA ratio) contents in liver were significantly affected by the level of protein in diet. The protein restricted diet caused a decrease in cellular protein contents in maternal liver but an increase in its cellular lipid content. The reduced ratios of protein to RNA contents in liver were also observed in protein restricted diet groups compared with those in control groups. No significant effect of ultrasonic energy exposure and its interaction with protein deficient diet was observed on any parameters tested for cellular changes in liver of dams.

\section{Fetal body composition and cellular components}

On the 18th day of gestation, fetal body composition as measured by percentages of water, protein, lipid and ash did not differ significantly among groups (Table 4). However, feeding dams a protein restricted diet during gestation had a significant influence on fetal cellular growth. Total DNA, RNA and protein contents per fetus from the dams fed the protein restricted diet were significantly less than those of controls. Moreover, the fetal contents of DNA, RNA, and protein were somewhat reduced due to ultrasonic energy exposure when dietary protein was restricted, although the reduction was not statistically significant. No difference among groups was observed in weight/DNA, protein/DNA, RNA/DNA and protein/DNA ratios in fetuses.

\section{Placental composition and its cellular components}

While neither ultrasonic energy nor its interaction with a protein restricted diet had an influence on parameters measured for placental cellular growth, feeding dams a protein restricted diet had a significant effect on some of the parameters presented in Table 5. Total protein and RNA contents per placenta from animals fed protein restricted diets during gestation were significantly reduced compared with those from animals fed control diets. In addition, placental RNA content appeared to be reduced due to ultrasonic energy exposure during gestation, but the reduction was not statistically significant. The apparent decrease in placental DNA content by either treatment was likewise not statistically significant. No differences were noted in ratios of weight to DNA, protein to DNA, protein to RNA, and RNA to DNA among groups.

Table 4. The combined effects of ultrasound and protein nutrition on body composition and cellular components of fetal mice ${ }^{1.2}$

\begin{tabular}{|c|c|c|c|c|c|c|c|c|c|c|c|c|}
\hline \multirow[b]{3}{*}{ Water $(x)$} & \multicolumn{12}{|c|}{ Treatment } \\
\hline & \multicolumn{3}{|c|}{$\mathrm{cs}$} & \multicolumn{3}{|c|}{$\mathrm{CA}$} & \multicolumn{3}{|c|}{$\underline{\mathrm{RS}}$} & \multicolumn{3}{|c|}{$\underline{R A}$} \\
\hline & 85.0 & \pm & 0.3 & 84.9 & \pm & 0.8 & 84.9 & \pm & 0.3 & 85.1 & \pm & 0.2 \\
\hline Prote1n (z) & 12.0 & \pm & 0.1 & 11.8 & \pm & 0.2 & 11.0 & \pm & 0.2 & 10.6 & + & 0.1 \\
\hline Lipld (z) & 2.1 & \pm & 0.1 & 2.1 & \pm & 0.1 & 2.3 & \pm & 0.1 & 2.1 & \pm & 0.2 \\
\hline Ash $(z)$ & 1.18 & \pm & 0.04 & 1.78 & \pm & 0.03 & 1.79 & \pm & 0.06 & 1.76 & \pm & 0.07 \\
\hline DNA (ng/fetus)*ૌ & 3.39 & \pm & 0.11 & 3.40 & \pm & 0.10 & 2.69 & \pm & 0.17 & 2.28 & \pm & 0.18 \\
\hline RNA (mg/fetus) ** & 6.15 & \pm & 0.18 & 6.09 & \pm & 0.17 & 4.63 & \pm & 0.22 & 4.43 & + & 0.19 \\
\hline Protein (ng/fetus) $\star \star$ & 130.4 & \pm & 5.8 & 131.1 & \pm & 6.6 & 95.8 & \pm & 3.6 & 91.6 & \pm & 6.0 \\
\hline Fetal Welght/DNA (ng/ag) & 329.7 & \pm & 14.6 & 328.6 & \pm & 18.8 & 328.7 & \pm & 21.0 & 355.3 & \pm & 43.7 \\
\hline Protein/DNA (ag/mg) & 38.8 & \pm & 2.4 & 38.7 & \pm & 2.0 & 36.9 & \pm & 2.3 & 41.5 & \pm & 3.4 \\
\hline RNA/DNA (mg/mg) & 1.82 & \pm & 0.07 & 1.80 & \pm & 0.06 & 1.74 & \pm & 0.06 & 1.99 & \pm & 0.13 \\
\hline Prote1n/RNA (ag/ag) & 21.2 & \pm & 0.7 & 21.4 & \pm & 0.6 & 20.0 & + & 1.2 & 20.6 & + & 0.3 \\
\hline
\end{tabular}



2 Wet weight besis

\#*A significant effect of protein-restricted dlet was shown at the level of $p<0.01$.
} 
Table 5. The combined effects of ultrasound and protein nutrition on placental composition and its cellular components of mice $^{1}$

\begin{tabular}{|c|c|c|c|c|c|c|c|c|}
\hline \multirow[b]{3}{*}{  } & \multicolumn{8}{|c|}{ Treatment } \\
\hline & \multicolumn{2}{|r|}{$\underline{\mathrm{CS}}$} & \multicolumn{2}{|r|}{$\underline{\mathrm{CA}}$} & \multicolumn{2}{|r|}{$\underline{\mathrm{RS}}$} & \multicolumn{2}{|r|}{ RA } \\
\hline & 18.16 & \pm 1.28 & 16.14 & \pm 0.52 & 14.45 & \pm 0.25 & 15.37 & \pm 0.90 \\
\hline DNA ( $\mu g /$ placenta) & 379.7 & \pm 22.6 & 349.6 & \pm 19.3 & 341.0 & \pm 11.1 & 320.1 & \pm 17.0 \\
\hline Placental Weight/DNA (mg/mg) & 271.3 & \pm 10.8 & 281.4 & \pm 17.2 & 261.3 & \pm 13.0 & 293.1 & \pm 16.9 \\
\hline Protein/DNA (mg/mg) & 49.1 & \pm 2.4 & 46.3 & \pm 3.7 & 42.7 & \pm 1.6 & 47.5 & \pm 2.4 \\
\hline RNA ( $\mu g /$ placenta $) *$ & 797.4 & \pm 54.4 & 684.3 & \pm 16.3 & 610.6 & \pm 24.5 & 659.3 & \pm 29.9 \\
\hline Protetn/RNA (mg/mg) & 24.4 & \pm 0.8 & 23.0 & \pm 0.7 & 24.0 & \pm 0.8 & 23.2 & \pm 1.0 \\
\hline RNA / DNA (mg/mg) & 2.01 & \pm 0.08 & 2.00 & \pm 0.13 & 1.80 & \pm 0.10 & 2.06 & \pm 0.11 \\
\hline
\end{tabular}

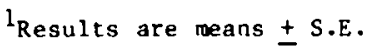

* A significant effect of protein-restricted diet was shown at the level of $p<0.05$.

**A significant effect of protein-restricted diet was shown at the level of $p<0.01$.
}

\section{DISCUSSION}

In this study, a significant reduction in daily food intake of dams was observed with the feeding of a restricted protein diet. This finding was also noted by other investigators in studies with the rhesus monkey, swine and the rat (Berg 1967; Kohrs et al., 1976; Pond et al. 1968). However, a restriction of dietary protein does not always have the effect of decreasing total food intake (Zamenhof et al. 1971). Since we observed a significant reduction in maternal food intake with protein restriction, it can be concluded that this treatment also had the effect of producing deficits of kilocalories and possibly of other dietary nutrients. To our knowledge, in no study that has been concerned with the effect of only ultrasound on the maternal or fetal organism has food intake been monitored. Therefore, this variable remains an unknown factor in many studies.

The reduced maternal body weight gain observed in protein restricted diet groups is likely due to the reduced total food intake. A reduction of maternal body weight gain was accompanied by reductions in maternal weight gain and the weights of uteri and component parts, such as fetuses, placentas, amniotic fluid and uterine tissue itself. These findings are consistant to those obtained with rats (Hastings-Roberts and Zeman 1977).

Stolzenberg et al. (1980a) observed a decrease in maternal body weight gain, the cause of which they suggested might be due to stress from exposure to ultrasound. Statistically significant decreases were noted for exposures on days 7 and 12 of gestation (adjusted to our convention that day zero is the day of mating) at a spatial average intensity (averaged within the $-3 \mathrm{~dB}$ contour) of 1 $\mathrm{W} / \mathrm{cm}^{2}$ for at least 100 and $160 \mathrm{sec}$, respectively. Their exposure conditions were greater than ours in that their intensity value was about a factor of two lower but their exposure times were at least a factor of 5 greater.

In view of the significant reduction in maternal liver weight in animals fed the restricted protein diet during gestation, it appears that maternal tissue was used to compensate for deficits of kilocalories and perhaps other dietary nutrients. Moreover, the absence of a significant difference in the ratio of liver weight to body weight among groups indicates the proportional decrease in liver weight to body weight.

A significant impact of the restricted protein diet on the chemical composition of the maternal liver was also found. The lipid content was higher and the protein content was lower in the liver of animals fed the restricted protein diet than in control animals. When the data were expressed in terms of relative amounts of lipid and protein per cell (lipid/DNA and protein/DNA), it became evident 
that animals fed the restricted protein diet had an increased cellular content of lipid but a decreased protein content per cell. Liver lipid accumulation found in the restricted protein group might be partly attributed to interference with the intracellular metabolism of lipids, since impairment of lipid transport due to decreased synthesis of the protein portion of the lipoprotein molecule has been suggested as a possible cause for fatty liver in the case of protein deficiency (Flores et al. 1970; Seakins and Waterlow, 1972; Truswell et al. 1969). The reduction of maternal liver protein content by dietary protein restriction may be due to a reduction of labile cytoplasmic proteins (Muramatsu et al. 1962; Wainio et al. 1959). These labile proteins would contribute amino acid to the metabolic pool for protein anabolism during pregnancy. In addition, liver protein anabolism was influenced since there was a reduction in the protein/RNA ratio, indicating a decrease in the quality of ribosome (decreasing polysomes into monosomes) as well as the amino acid supply. Cell number was not affected by lowering the protein content in the diet of dams whereas cell size was affected. Feeding a restricted protein diet during gestation led to an increased concentration of liver DNA ( $\mathrm{mg} / \mathrm{g}$ liver), but the total DNA content in liver $(\mathrm{mg} /$ liver) was not changed in these animals.

Gestational performance data indicated a pronounced effect of dietary protein on the maintenance of pregnancy as measured by resorptions and litters size. However, these results differ from those reported by Zeman (1967), who fed pregnant rats either 24 or $6 \%$ casein diet, and found normal maintenance of pregnancy in the rats fed a restricted protein diet. This apparent discrepancy can be explained by either species difference (mice vs rats) or the fact that Zeman (1967) did not observe a significant reduction in food intake when restricting dietary protein. In other words, it can be concluded that the impact of protein restriction on gestational performance of animals might differ from one species to another, and caloric intake during pregnancy is an important factor in maintaining pregnancy.

The restriction of protein content in diet during pregnancy in mice resulted in the production of young with a lower fetal body weight than of control animals on day 18 of gestation. This observation is in agreement with those of other investigators (Nelson and Evans 1953; Zeman 1967). The fetal body composition analyses also suggest that the growth retardation was not selective but uniform. Certain tissues were not spared at the expense of others during protein restriction since there were no significant differences in percentage fetal body composition among treatments.

A comparison of fetal DNA contents among groups indicates that there are fewer cells from the protein restricted groups than those fed the control diet. However, there was no change in fetal cellular size as indicated by either weight/DNA or protein/DNA ratios. Since a significant reduction in fetal RNA content without a change in the protein/RNA ratio was observed, it is assumed that the reduction in fetal protein content in protein restricted groups resulted from a decrease in the fetal RNA content. Although there were no differences in average placental weight and DNA content of placenta among groups, there were decreases in both placental protein and RNA contents which parallel the results observed in the fetus. These findings suggest the fetus is vulnerable to environmental stress, even more so than other products of conception. While it is often assumed that nutritional needs for fetal growth can be provided at the expense of the maternal organism (Committee on Maternal Nutrition 1970), our findings suggest that competition for available nutrients may exist between the fetus and the maternal organism under our experimental condition. A positive correlation between maternal liver protein content and fetal protein was found. This result indicates that the adverse effects of protein restriction were manifested on both maternal and fetal animals.

It has been suggested that the trends in fetal growth and placental growth are in the same general direction (Rosso 1981). Results from this study lend support for this concept. While a positive correlation between placental and fetal protein/DNA ratios was noted, there was no difference in the ratio of fetal weight to placental weight among groups.

Our experimental data also suggest that there are possible effects of ultrasonic energy exposure to the fetus and the placenta. The tendency toward decreased fetal and placental weights on day 18 of gestation was noticeable with ultrasonic energy exposure, only when protein content was restricted in the maternal diet. The trends for the differences in the DNA and RNA contents of both fetus and placenta were similar to the trends observed for weights of these products of conception. However, the apparent differences were not marked enough to show statistical significance. These are unexpected observations since the choice of the ultrasonic exposure conditions reported herein $(2.5$ 
$\mathrm{W} / \mathrm{cm}^{2}$ for $20 \mathrm{sec}$ ) was based upon the work of O'Brien (1976 and 1982) wherein it was thought that due to the ultrasound treatment alone, there would be approximately a $6 \%$ decrease in the fetal weight compared to that of the sham. A larger number of animals might be necessary to reveal statistically significant differences, but it should be noted that the possibility exists for abnormal growth of both the fetus and placenta from ultrasonic energy exposure during the prenatal period.

It is important to point out that the effects of ultrasonic energy exposure may only be evident during the postnatal period. This speculation is supported by previous findings (Januzik 1976; O'Brien et al. 1982). In the study of $\mathrm{LAF}_{1} / \mathrm{J}$ mice exposed to ultrasonic energy during the prenatal period, they were not able to observe a negative effect of ultrasonic energy on fetal weight on the 18th day of gestation, but a statistically significant body weight reduction was observed in irradiated animals after birth (on the 21 st day of postconception). On the other hand, in the study of different strain of mice ( $C F_{1}$ mice) exposed to ultrasonic energy during gestation, especially during the period of neurogenesis and early organogenesis, a significant weight reduction was evident at the 18th day of gestation. Therefore, it can be concluded that there may be possible risks of ultrasonic energy exposure during the reproductive life of an individual when protein is restricted, and stresses the need to assess the safety for the fetus under other conditions of environmental stress. It should be pointed out, however, that severe protein deficiency is rare in pregnant humans, but it does exist. If and to what extent this population group receives ultrasound are not known.

Acknowledgements-We are indebted to Dr. Robert D. Seif, Professor of Biometry, for his consultation with respect to statistics and its interpretation. This research was supported, in part, by grants from the Illinois Agricultural Experiment Station (338) and from the U.S. Food and Drug Administration (FD 665 and FD 927) and from the U.S. National Institute of General Medical Sciences (GM 30481).

\section{REFERENCES}

Association of Official Analytical Chemists (1975) Official Methods of Analysis, A.O.A.C., p. 566, Washington, D.C.

Berg B. N. (1967). Maintenance of pregancy in protein-deprived rats by transitory protein supplements during early gestation. J. Nutr. 92, 66-70.

Burke B. S., Harding V. V. and Stuart H. C. (1943) Nutrition studies during pregnancy. IV. Relation of protein content of mother's diet during pregnancy to birth length, birth weight and condition of infant at birth. J. Pediat. 23, 506-515.

Ceriotti G. (1955). Determination of nucleic acids in animal tissues. J. Biol. Chem. 214, 59-70.

Committee on Maternal Nutrition (1970). Maternal Nutri- tion and the Course of Pregnancy. National Academy of Sciences, Washington, D.C.

Draper N. R. and Smith H. (1966). Applied Regression Analyses. Wiley, New York.

Dunn, F., Averbuch, A. J. and O'Brien, W. D., Jr. (1977). A primary method for the determination of ultrasonic intensity with elastic sphere radiometer. Acustica 38, 58-61.

Fleck A. and Munro H. N. (1962). The precision of ultraviolet absorption measurements in the Schmidt-Thanhauser procedure for nucleic acid estimation. Biochimica et Biophysica Acta 55, 571-583.

Flores H., Pak N., Maccioni A. and Monckeberg F. (1970) Lipid transport in kwashiorkor. Br. J. Nutr. 24, 1005-1011.

Folch J., Lees M. and Stanely G. H. S. (1957) A simple method for the isolation and purification of total lipids from animal tissues. J. Biol. Chem. 226, 497-509.

Gottesfeld K. R. (1978). Ultrasound in obstetrics. Clin. Obst. Gynecol. 21, 311-327.

Hastings-Roberts M. M. and Zeman F. J. (1977) Effects of protein deficiency, pair-feeding, or diet supplementation on maternal, fetal and placental growth in rats. J. Nutr. 107, 973-982.

Hubbard, R. W., Mathew W. T. and Dubowik D. A. (1970). Factors influencing the determination of DNA with indole. Anal. Biochem. 38, 190-201.

Januzik S. J. (1976). Two studies of biological effects due to ultrasonic irradiation. M. S. Thesis. University of Illinois, Urbana, IL.

Kim H. L., Picciano M. F. and O'Brien W. D., Jr., (1981) Influence on maternal dietary protein and fat levels on fetal growth in mice. Growth 45, 8-18.

Kohrs M. B., Harpen A. E. and Kerr G. R. (1976). Effects of a low-protein diet during pregnancy of the rhesus monkey: $I$. Reproductive efficiency. Am. J. Clin. Nutr. 29, 136-145.

Lechtig A., Habicht J. P., Delgado H., Klein R. E., Yarborough C. and Martorell R. (1975) Effect of food supplementation during pregnancy on both birth weight. Pediat. 56, 508-520.

Leshner A. I. and Litwin V. A. (1972) Brief communication: A simple method for carcass analysis. Physiol. and Behavior 9, 281-282.

Metcaff J., Costiloe J. P., Crosby W., Bentle L., Seshachalam D., Sanstead H. H., Bodwell C. E., Weaver F. and McClain P. (1981). Maternal nutrition and fetal outcome. Am. J. Clin. Nutr. 34, 708-721.

Muramatsu K. and Ashida K. (1962) Effects of dietary protein level on growth and liver enzyme activities of rats. $J$. Nutr. 76, 143-150.

NAS/NRC (1978). Nutrient Requirements of Laboratory Animals. 3rd Edn. National Academy of Sciences, Washington, D.C.

Nelson, M. M. and Evans, H. M. (1953). Relation of dietary protein levels to reproduction in the rat. $J$. Nutr. 51, 71-84.

O'Brien, W. D., Jr. (1976). Ultrasonically induced fetal weight reduction in mice. In Ultrasound in Medicine (Edited by D. White and R. Barnes) Vol. 2, pp. 531-532, Plenum Press, New York.

O'Brien, W. D., Jr. (1982). Ultrasonic dose-dependent effect upon fetal weight in mice. J. Ultrasound Med. in press.

O'Brien W. D., Jr., Januzik S. J. and Dunn F. (1982) Ultrasound biological effects: A suggestion of strain specificity. $J$. Ultrasound Medicine in press.

Pond W. G., Wagner W. C., Dunn J. A. and Walker E. F., Jr. (1968). Reproduction and early postnatal growth of progeny in swine fed a protein-free diet during gestation. $J$. Nutr. 94, 309-316.

Rosso P. (1981) Nutrition and maternal-fetal exchange. Am. J. Clin. Nutr. 34, 744-755.

Rugh R. (1968). The mouse: its reproduction and development. Burgess Publishing Company, Minneapolis, NM.

Seakins A. and Waterlow J. C. (1972) Effects of low-protein diet on the incorporation of amino acids into rat serum lipoproteins. Biochem. J. 129, 793-795. 
Steel R. G. D. and Torrie J. H. (1960) Principles and Procedures of Statistics with Special Reference to the Biological Sciences pp. 161-193. McGraw-Hill, New York, NY.

Stolzenberg S. J., Torbit C. A., Edmonds P. D. and Taenzer J. C. (1980a) Effects of ultrasound on the mouse exposed at different stages of gestation: acute studies. Radiat. Environ. Biophys. 17, 245-270.

Stolzenberg S. J., Torbit C. A., Pryor G. T. and Edmonds P. D. (1980b) Toxicity of ultrasound in mice: neonatal studies. Radiat. Environ. Biophys. 18, 37-44.

Stratmeyer M. E., Simmons L. R., Pinkavitch F. Z., Jessup G. L. and O'Brien W. D., Jr. (1977) Growth and development of mice exposed in utero to ultrasound. In. Symp. on Biological Effects and Characterization of Ultrasound Sources. DHEW Publication (FDA) 78-8048, U.S. Government Printing Office, Washington, D.C.

The University Federation for Animal Welfare (1976). The UFA W Handbook on the Care and Management of Laboratory Animals. p. 162. Churchill Livingstone, New York, NY.

Truswell A. S., Hansen D. L., Watson C. E. and Wannenburg P.
(1969) Relation of serum lipids and lipoproteins to fatty liver in kwashiorkor. Am. J. Clin. Nutr. 22, 568-576.

Wainio W. W., Allison J. B. and Kremzner L. T. (1959) Enzymes in protein depletion. J. Nutr. 67, 197-204.

Winick M. and Noble A. (1966). Quantitative changes in ribonucleic acids and protein during normal growth of rat placenta. Nature 212, 34-35.

Winick M., Coscia A. and Noble A. (1967) Cellular growth in human placenta: I. Normal Placental growth. Pediat. 39. 248-251.

Zamenhof S., Marthens E. V. and Granel L. (1971) DNA (cell number) and protein in neonatal rat brain: Alternation by timing of maternal dietary protein restriction. J. Nutr. 101, 1265-1269.

Zeman F. J. (1967) Effect on the young rat of maternal protein restriction. J. Nutr. 93, 167-173.

Zeman F. J. and Stanbrough E. C. (1969). Effect of maternal protein deficiency on cellular development in the fetal rat. $J$. Nutr. 99, 274-282. 